\title{
Feasibility Testing of Mini Rice Mill Operation in Animal Driven Rotary Mode System
}

\author{
Aswani Kumar Korram ${ }^{1 *}$, S.V. Jogdand ${ }^{1}$, V.M. Victor ${ }^{1}$, \\ Animesh Chandravanshi ${ }^{1}$ and Sameer Mandal $^{2}$ \\ ${ }^{l}$ Department of Farm Machinery and Power Engineering, SVCAET\&RS, FAE, IGKV, \\ Raipur, (CG), India \\ ${ }^{2}$ Department of Soil and Water engineering, SVCAET\&RS, FAE, IGKV, Raipur, (CG), India \\ *Corresponding author
}

\section{Keywords}

Power transmission, Mini rice mill, Dynamometer, Draft, Fatigue Score

Article Info

Accepted:

20 January 2018

Available Online:

10 February 2018

\section{A B S T R A C T}

India has large population of draught animals and bullocks are main draft animals in the country followed by he-buffaloes. This study is to be focus on feasibility testing of mini rice mill operation in animal driven rotary mode system for operating mini rice mill. A study was conducted for operating a mini rice mill with the help of a rotary gear complex, installed in the premises of Swami Vivekananda College of Agricultural Engineering and Technology and Research Station, Faculty of Agricultural Engineering, Indira Gandhi Krishi Vishwavidyalaya, Raipur (CG). The experiment was conducted continuously for 3 hours with the measurement of milling efficiency, milling rate and cost of operation and compared with electric operated mini rice mill and physiological responses of bullocks like respiration rate, pulse rate, body temperature and fatigue score of experimental bullocks in operations of rice milling were recorded. Mini rice mill was also evaluated for performances in developed rotary transmission system. The Power generated by the bullock pair in a developed rotary transmission system and Output of mini rice milling operation were varies significantly with speed of local bullock pair during all operations. The draft exerted by bullocks, speed of bullocks, power generated and output of mini rice mill during work rest cycle were varied from 48.60 to $46.06 \mathrm{~kg}, 2.09$ to $1.84 \mathrm{kmph}, 0.27$ to $0.24 \mathrm{~kW}$ and 93.06 to $81.90 \mathrm{~kg} / \mathrm{hr}$, respectively. The output of mini rice mill by using developed animal driven rotary power transmission system was lower than that of in electrical operation. The total cost of operation of bullock operated mini rice mill was Rs. 127.91per hour $90.12 \square$ /q. Due to fluctuation of speed in rotary mode, the performance of the mini rice milling was lower in a rotary power transmission system than that of in the electrically operations.

\section{Introduction}

In rural areas electricity is either unavailable or available for limited time period. So performing many activities with the help of animal driven rotary mode power can be a good alternative. Draught animal are used for a limited time period for agricultural work 40 to 50 days and rest of the time they stand idle. The farmer has to feed them throughout the year despite no work output during off season, leading to high maintenance cost as compared 
to power output. But this idle period can be utilized and converted to work through rotary mode operation. The bullocks can be used in rotary mode power transmission system, postharvest operations like mini rice mill, flour milling, chaff cutting, dal milling, groundnut decortications, oil extraction, threshing and other stationery operations.

Milling is most important aspect of post harvesting operation of paddy mini rice mill consists of $\mathrm{V}$ belt drive and gear amplification mechanism that turn huller shaft in housing filled with paddy. This system removes the husk and the bran layer from rice and if this rice mill is operated by rotary mode unit, then energy cost can be saved with environment friendly operation. Development of matching agro processing machines to be used in rotary mode power transmission system is helpful to the farmers to use their animals in idle time and save electricity and other fuels and may earn more by lending this facility to others.

\section{Materials and Methods}

Experiment was conducted at College of Swami Vivekananda College of Agricultural Engineering and Technology and Research Station, Faculty of Agricultural Engineering, Indira Gandhi Krishi Vishwavidyalaya, Raipur (CG). The developed animal driven rotary mode system was evaluated for its performance for mini rice mill operation. During the test, bullocks were hitched at a distance of $5 \mathrm{~m}$ from the centre of vertical input shaft. The bullocks walked in circular motion that resulted on an average 2.0 RPM at vertical input shaft 1400 RPM at pulleys of mini rice mill. Gadgets, which are operated by $1 \mathrm{hp}$ motor can be easily operated by the animal driven rotary mode system. However, in the present study, an effort has been made to run a mini rice mill which is run by $2 \mathrm{hp}$ motor. The developed animal driven rotary transmission system was designed for $1 \mathrm{hp}$ power output. The work rest schedule of 1.5 hour work 1 hour rest then again 1.5 hour work. The speed (kmph), Draft (kg), Output (kg/hour), Power developed (kW), Physiological responses and Fatigue score of local bullocks mini rice milling operations were recorded.

\section{Animal powered rotary unit}

The rotary unit is developed to convert the animal power into mechanical power for operating the different agricultural processing machines. To make the complete unit economically viable, one pair of bullocks was used to generate power. For safer design of animal powered rotary unit, the ultimate power developed by a pair of bullocks can be assumed as $0.75 \mathrm{~kW}$. This power was used to operate some agricultural processing machinery like paddy thresher and chaff cutter, flour mill, mini rice mill etc., but in this case specially used for mini rice mill.

\section{Evaluation of power transmission system}

The developed power transmission system was evaluated by computing the power, draft and power output. The load was applied only after the bullocks attained the desired working speed. The dynamometer was mounted between yoke and beam, such that the pull exerted by the bullocks was applied to the beam through the dynamometer and which showed the instantaneous pull acting at the beam. The recorded draught was used to calculate input power. Test bullocks were hitched and allowed to move on a circular track. The system was tested at loads. The resulted draft was measured using dynamometer.

\section{Physiological responses of bullocks}

The experiment was conducted during summer (March-April) season. Trials were 
conducted using following work-rest schedule. $1 \mathrm{~h}$ work $+0.5 \mathrm{~h}$ rest $+1 \mathrm{~h}$ work $+0.5 \mathrm{~h}$ rest + $1 \mathrm{~h}$ work $+0.5 \mathrm{~h}$ rest $+1 \mathrm{~h}$ work during the rest period animals were kept in shed and also given feed and water. The environmental temperature started declining in the evening session and animals work up till the natural light was available. Hence, on an average the animals worked for 3 hour per day. The physiological responses such as respiration rate, pulse rate and body temperature were recorded at the start of work as initial values. Then, after every hour of work the observation were recorded for physiological responses and physical symptoms for both the bullocks separately. The bullock moving in the outer circle was termed as outer bullock and the one moving inside was called inner bullock. The average speed was also calculated.

\section{Performance evaluation of mini rice mill}

A commercially available mini rice mill of 2 hp required manufactured by maharaja machinery store, Raipur, Chhattishgarh was used. It was modified for using it in rotary transmission unit. The Mini Rice Mill of capacity $2 \mathrm{hp}$ was evaluated for its performance in developed animal driven rotary transmission system. MTU (1010) paddy grains were milling in it. An output capacity in $\mathrm{Kg}$ per hour was measured in respect of animal and electric operated. The output capacity of selected Mini Rice Mill operated by animal driven rotary transmission system was also compared with an electric operated Mini Rice Mill of $2 \mathrm{Hp}$ respectively.

\section{Economic viability}

Cost estimation was done under two heads fixed cost and variable cost. Fixed cost consists of: cost of power transmission system, pair of bullocks, civil work (earth work) and installation of transmission unit, plastering etc. and their depreciations.
Variable cost consists of labor charges, maintenance of mechanical systems, feed fodder etc. Total expenditure was calculated as sum of fixed cost and variable cost.

\section{Results and Discussion}

A developed rotary transmission system was evaluated for its performances in Mini Rice Milling operation in working of 3 hours at load conditions. The physiological behavior of bullock (B1 and B2) in a developed rotary mode system for Mini Rice milling operation were observed for obtaining maximum work efficiency without undue fatigue. The tests were carried out on the test track for continuous three effective hours of work duration. The various physiological parameters of bullock were recorded during experiment. The level of fatigue was assessed using fatigue score card developed by Upadhyay and Madan (1985).

\section{Performance evaluation of developed animal driven rotary transmission system under an operation of mini rice mill at load condition}

Table 4 demonstrate that at load condition an average speed of local bullock pair was decreased from 2.09 to $1.84 \mathrm{kmph}$ during three hours of work. Draft exerted by the bullock pair was varies from 48.60 to 46.06 $\mathrm{kg}$. Speed available at mini rice mill was also observed to be decreased from 1452 to 1358 RPM. Similarly, Power generated was also decreased from 0.27 to $0.24 \mathrm{~kW}$ at the same condition. The output of mini rice mill was varies from 93.06 to $81.90 \mathrm{~kg} / \mathrm{hr}$.

The respective average values of Draft, Average speed of bullock pair, Speed available at mini rice mill, Power output and Output of mini rice mill were $47.33 \mathrm{~kg}, 1.94$ $\mathrm{kmph}, 1405.50 \mathrm{RPM}, 0.25 \mathrm{~kW}$ and 89.38 $\mathrm{kg} / \mathrm{hr}$ respectively at load condition. 
Table.1 Physical dimensions and other details of bullocks used as power source

\begin{tabular}{|c|c|c|}
\hline S. NO. & Particular & Specification \\
\hline 1. & $\begin{array}{l}\text { Screw dimensions: } \\
\text { Screw pitch, } \mathrm{mm} \\
\text { Screw length, } \mathrm{mm} \\
\text { Diameter of screw, mm }\end{array}$ & $\begin{array}{c}10 \\
300 \\
40\end{array}$ \\
\hline 2. & $\begin{array}{l}\text { Pulley and belt: } \\
\text { Diameter of driving pulley, mm } \\
\text { Belt type }\end{array}$ & $\begin{array}{c}100 \\
\text { v- belt }\end{array}$ \\
\hline 3. & $\begin{array}{l}\text { Overall dimensions: } \\
\text { Overall length of machine, } \mathrm{mm} \\
\text { Overall width of machine, } \mathrm{mm} \\
\text { Overall height of machine, } \mathrm{mm} \\
\text { Hopper diameter, mm }\end{array}$ & $\begin{array}{l}400 \\
280 \\
600 \\
380\end{array}$ \\
\hline $\begin{array}{l}4 . \\
5 . \\
6 .\end{array}$ & $\begin{array}{l}\text { Rpm of the machine } \\
\text { Capacity } \\
\text { Power requirement }\end{array}$ & $\begin{array}{c}1400 \\
150-200 \\
2 \mathrm{HP}\end{array}$ \\
\hline
\end{tabular}

Table.2 Parameters of Mini Rice Mill operated in rotary mode condition

\begin{tabular}{|c|c|c|c|c|c|c|c|}
\hline \multirow[t]{2}{*}{ Parameters } & \multicolumn{6}{|c|}{ Duration (h) } & \multirow[t]{2}{*}{ Average } \\
\hline & 0.5 & 1 & 1.5 & 2 & 2.5 & 3 & \\
\hline $\begin{array}{l}\text { Variety } \\
\text { (MTU) }\end{array}$ & 1010 & 1010 & 1010 & 1010 & 1010 & 1010 & 1010 \\
\hline $\begin{array}{c}\text { Mc of paddy } \\
(\%)\end{array}$ & 10 & 10 & 10 & 10 & 10 & 10 & 10 \\
\hline $\begin{array}{l}\text { Speed of } \\
\text { mini rice } \\
\text { mill (rpm) }\end{array}$ & 1452 & 1442 & 1418 & 1405 & 1358 & 1358 & 1405.5 \\
\hline $\begin{array}{l}\text { Weight of } \\
\text { rice }(\mathrm{kg})\end{array}$ & 46.53 & 95.89 & 135.82 & 181.31 & 227.18 & 268.13 & 44.68 \\
\hline $\begin{array}{l}\text { Weight of } \\
\text { husk (kg) }\end{array}$ & 23.80 & 41.20 & 60.68 & 84.25 & 102.15 & 121.53 & 20.25 \\
\hline $\begin{array}{l}\text { Weight of } \\
\text { broken (kg) }\end{array}$ & 6.08 & 12.11 & 17.63 & 24.14 & 30.30 & 36.35 & 6.05 \\
\hline $\begin{array}{c}\text { Milling } \\
\text { Efficiency } \\
(\%)\end{array}$ & 60.80 & 67.80 & 61.50 & 60.20 & 65.60 & 61.70 & 62.93 \\
\hline Husk (\%) & 31.10 & 23.90 & 30.00 & 31.20 & 25.60 & 29.20 & 28.50 \\
\hline Broken (\%) & 13.32 & 12.24 & 13.82 & 14.28 & 13.41 & 14.47 & 13.63 \\
\hline
\end{tabular}


Table.3 Milling rate $(\mathrm{kg} / \mathrm{h})$ of mini rice mill operated in rotary mode

\begin{tabular}{|c|c|c|c|c|}
\hline S. No. & $\begin{array}{c}\text { Output of rice } \\
(\mathrm{kg} / \mathrm{h})\end{array}$ & $\begin{array}{c}\text { Output of husk } \\
(\mathrm{kg} / \mathrm{h})\end{array}$ & $\begin{array}{c}\text { Output of broken } \\
(\mathrm{kg} / \mathrm{h})\end{array}$ & $\begin{array}{c}\text { Milling rate } \\
(\mathrm{kg} / \mathrm{h})\end{array}$ \\
\hline 1 & 93.06 & 47.60 & 12.16 & 153.06 \\
\hline 2 & 98.74 & 34.81 & 12.06 & 145.59 \\
\hline 3 & 79.87 & 38.96 & 11.04 & 129.37 \\
\hline 4 & 90.98 & 47.15 & 13.02 & 151.12 \\
\hline 5 & 91.75 & 35.80 & 12.32 & 139.74 \\
\hline 6 & 81.90 & 38.80 & 12.10 & 132.73 \\
\hline Average & 89.38 & 40.52 & 12.12 & 141.94 \\
\hline
\end{tabular}

Table.4 Physiological responses of bullocks

\begin{tabular}{|c|c|c|c|c|c|c|}
\hline $\begin{array}{c}\text { Parameters } \\
\text { Time }\end{array}$ & $\begin{array}{l}\text { Pulse Rate } \\
\text { (bpm) }\end{array}$ & $\begin{array}{c}\text { Resp. Rate } \\
\text { (bpm) }\end{array}$ & $\begin{array}{c}\text { Body } \\
\text { temperature }\left({ }^{\circ} \mathrm{C}\right)\end{array}$ & Fatigue & $\begin{array}{c}\text { Speed } \\
(\mathrm{km} / \mathrm{h})\end{array}$ & $\begin{array}{c}\text { Power } \\
\text { Output (kW) }\end{array}$ \\
\hline Initial & 42.00 & 24.00 & 37.00 & & $\ldots .$. & $\ldots \ldots$ \\
\hline$\frac{1}{2}$ & 44.00 & 27.00 & 38.00 & 2.00 & 2.09 & 0.27 \\
\hline 1 & 47.06 & 35.00 & 39.00 & 6.00 & 1.96 & 0.26 \\
\hline $1 \frac{1}{x}$ & 53.00 & 43.00 & 39.75 & 9.00 & 1.86 & 0.24 \\
\hline 1hour rest & $\ldots \ldots$ & ...... & $\ldots \ldots$ & $\ldots \ldots$ & $\ldots \ldots$ & $\ldots \ldots$ \\
\hline Initial & 44.00 & 27.00 & 37.16 & 6.00 & $\ldots \ldots$ & $\ldots \ldots$ \\
\hline 2 & 48.00 & 34.00 & 39.00 & 8.00 & 2.01 & 0.26 \\
\hline $2 \frac{1}{5}$ & 54.00 & 45.00 & 39.25 & 11.00 & 1.93 & 0.25 \\
\hline 3 & 58.00 & 50.00 & 40.00 & 14.00 & 1.84 & 0.24 \\
\hline Average & 48.75 & 35.62 & 38.64 & 8.00 & 1.94 & 0.25 \\
\hline
\end{tabular}

Fig.1 Animal power rotary mode unit

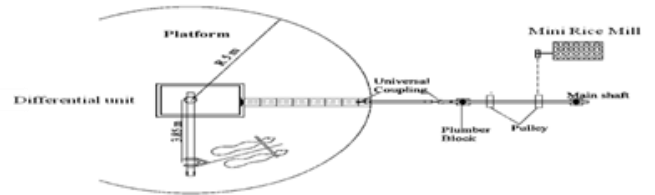

Fig.2 Developed mini rice mill

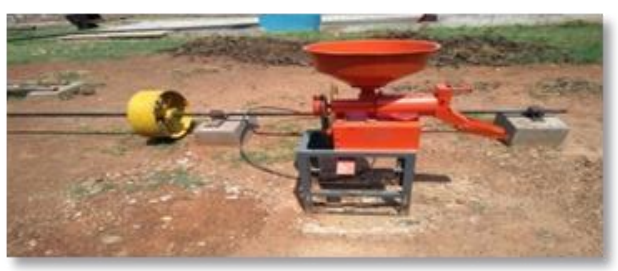


Fig.3 Physiological Responses and performance evaluation of mini rice mill
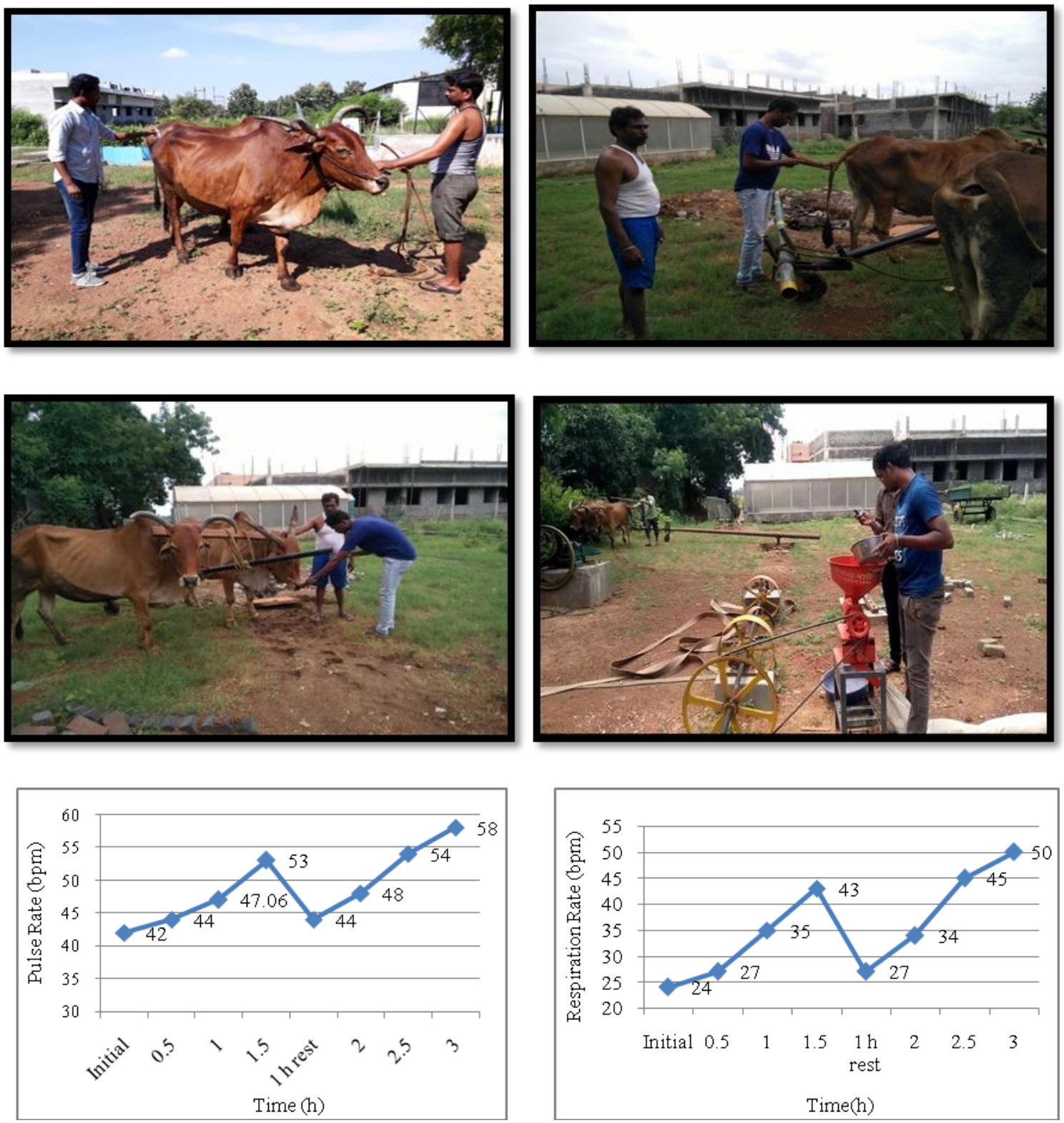

Fig.4 Pulse rate of bullocks

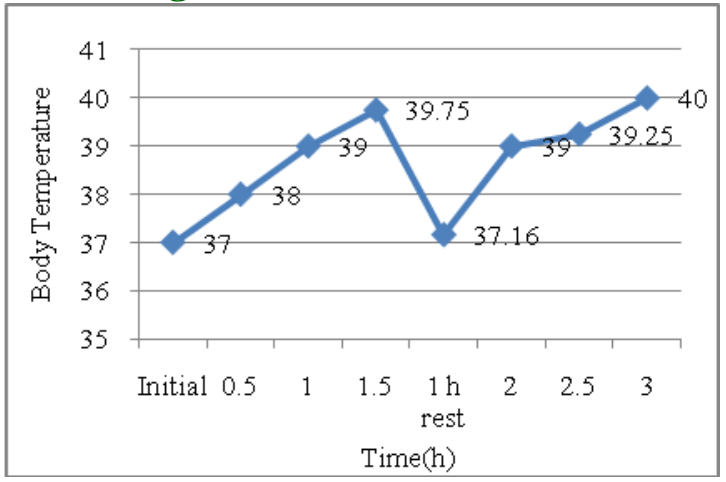

Fig.6 Body temperature of bullocks

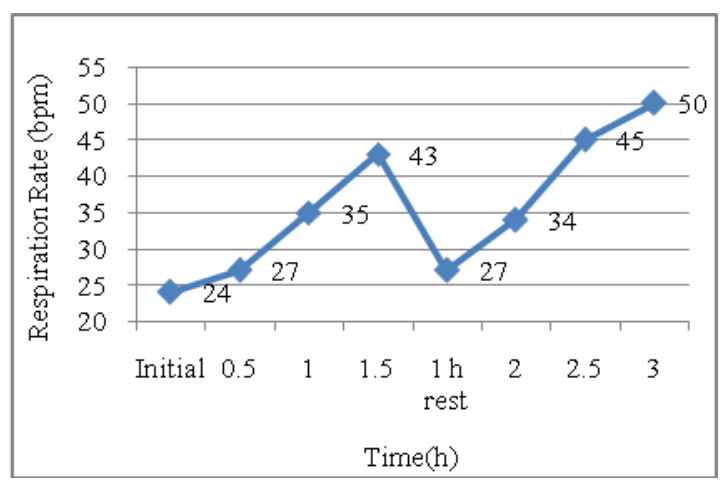

Fig.5 Respiration rate of bullocks

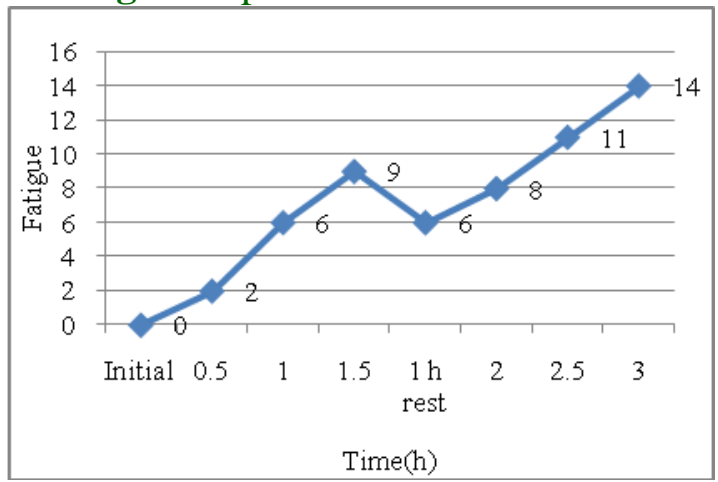

Fig.7 Fatigue scores of bullocks 


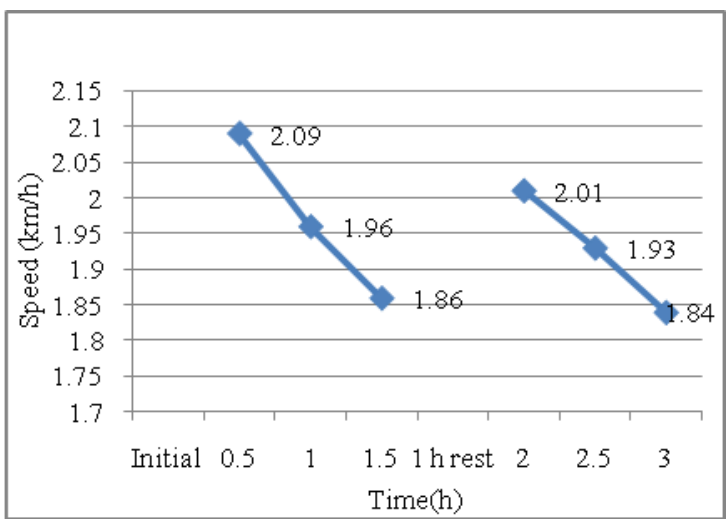

Fig.8 Speed of bullocks

Determination of work rest schedule for bullock for developed rotary power transmission system in operation of selected matching gadgets

A pair of bullock was used to operate mini rice mill having $2 \mathrm{hp}$ required. The work rest schedule of 1.5 hour work 1 hour rest then again 1.5 hour work. This work rest cycle was adopted to get maximum performance from the selected local bullocks.

It is due to the fact that, the bullocks gives better performance in continuous 1.5 hour of work. During the experiment period, fatigue score of bullock noted according to Madan and Upadhyay (1985) by observing behavioural changes as well as by recording physiological responses after half an hour.

\section{Comparison of outputs of animal drawn} rotary power transmission system and electrical operated mini rice mill

The comparison between outputs of bullock operated, and electrical operated mini rice mill shows that average output of rice mill operated by electric motor was higher (116.06 $\mathrm{kg} / \mathrm{h}$ ) than the rice mill operated by rotary mode $(89.38 \mathrm{~kg} / \mathrm{h})$. Husk output was observed to be $50.36 \mathrm{~kg} / \mathrm{h}$ and $40.52 \mathrm{~kg} / \mathrm{h}$ whereas broken output was found to be $10.61 \mathrm{~kg} / \mathrm{h}$ and $12.12 \mathrm{~kg} / \mathrm{h}$ respectively for both the systems. Milling efficiency of rice mill operated by

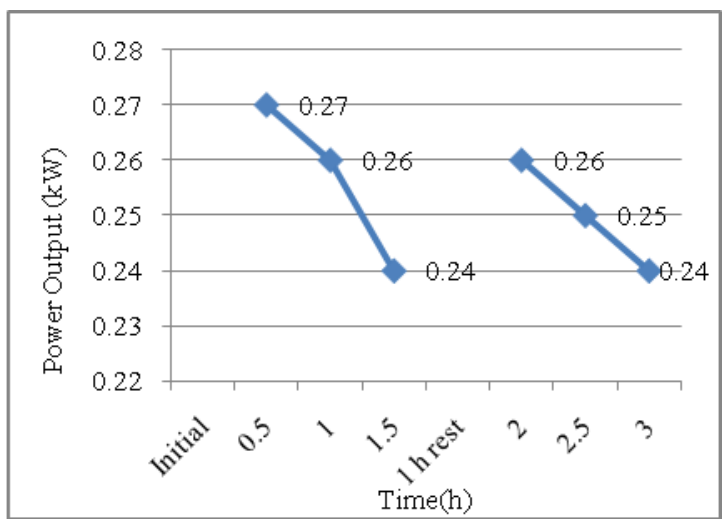

Fig.9 Power output of bullocks

rotary mode $(62.93 \%)$ was found very close to electric operated unit $(64.34 \%)$ ). It is clear that, an output of bullock operated mini rice mill is lower than that of output of an electrically operated.

\section{Cost economics of animal driven rotary transmission system for operating mini rice mill}

The total cost of developed animal driven rotary mode unit for operating Mini Rice Mill with pair of bullock is Rs.127.91 per hour Cost.

On the basis of various studies conducted in the present research work following conclusions are drown.

Output under electric operated rice mill was however higher compared to operation by rotary mode system, which may be due to uneven speed of bullocks and uneven feeding rate. But it was revealed that, the operation of milling using rotary mode is possible.

However, the output of mini rice mill under the rotary mode was lower than electric operated mill, but the use of animal power increase annual use of bullocks and thereby saves electric energy.

The total cost of operation of bullock operated mini rice mill were Rs. 127.91 per hour. 
Due to fluctuation of speed in rotary mode, the performance of the mini rice milling was lower in a rotary power transmission system than that of the in the electrically operations.

\section{References}

Anonymous, 2000. Annual Report of All India Coordinated Research Project on Utilization of Animal Energy with Enhanced System Efficiency. Department of Farm Machinery \& Power Engineering. College of Technology and Engineering, Udaipur, (Raj.).

Devendra Kumar 1982. Design of a bullock drawn centrifugal pump. B.Tech. Thesis, G. B. Pant University of Agriculture and Technology, Pantnagar. Jaswant Singh 1987. Draught animal power for oil extraction. Proceedings of the national seminar on status of animal energy utilization held at CIAE, Bhopal, and pp. 269-274.

Kailappan, R., Ramasamy C. and Kareem A. A. 1993. A practical device in manual paddy threshing. Agricultural Mechanization in Asia, Africa and Latin America Vol. 24(2):24-26.

Khepar, S.D., Kaushal M.P. and Katyal A. K. 1975.Development of an animal drawn lift irrigation pump. J. Agric. Engg. Vol.12 (3-4): 24-25.

Maurya N. L. and Devdattam D. S.K. 1982. Work performance of bullocks. Indian Journal of Dairy Science. Vol. 35(1):2630.

Ranganna, S., 1995. Hand book of analysis and quality control for fruit and vegetable products. Tata McGraw-Hills Publishing Company Limited, New Delhi.

Sahuparmanand 2015. Development of Animal Power Briquetting Machine to Produce Low Density Briquettes. International Journal of Engineering Research \& Technology (IJERT) Vol. 4 (7), July-2015.

Singh, M. P and Thakur. T. C. 1990. Investigations on utilization of animal power for operating various rotary powered machines. Proceedings of the international agricultural engineering Conference and exhibition, Bangkok, Thailand.

Singh, S. P., Sony B. K. and Bhattacharya N. K. 1968. Physiological response in Haryana bullocks while performing different types of agricultural operations. Indian Veterinary Journal.45: 30.

\section{How to cite this article:}

Aswani Kumar Korram, S.V. Jogdand, V.M. Victor, Animesh Chandravanshi and Sameer Mandal. 2018. Feasibility Testing of Mini Rice Mill Operation in Animal Driven Rotary Mode System. Int.J.Curr.Microbiol.App.Sci. 7(02): 2433-2440. doi: https://doi.org/10.20546/ijcmas.2018.702.296 